\title{
Preliminary Results of a Randomized, Equivalence Trial of Fluoroscopic Caudal Epidural Injections in Managing Chronic Low Back Pain: Part 1 - Discogenic Pain without Disc Herniation or Radiculitis
}

Laxmaiah Manchikanti, MD¹, Kimberly A. Cash, RT1ㅜ, Carla D. McManus, RN, BSN¹, Vidyasagar Pampati, MSc' ${ }^{1}$, and Howard S. Smith, MD ${ }^{2}$

From: ${ }^{1}$ Pain Management Center of Paducah, Paducah, KY; and ${ }^{2}$ Albany Medical College, Albany,

Dr. Manchikanti is Medical Director of the Pain Management Center of Paducah, Paducah, $\mathrm{KY}$, and Associate Clinical

Professor of Anesthesiology and Perioperative Medicine, University of Louisville, Louisville,

Ms. Cash is a Rest Coordinator at the Pain Management Center of Paducah, Paducah, KY.

Ms. McManus is a Nursing Administrator at the Pain Management Center of Paducah, Paducah, KY.

Mr. Pampati is a Statistician at the Pain Management Center of Paducah, Paducah, KY. Dr. Smith is Associate Professo and Academic Director of Pain Management for Albany Medical College Department of

Anesthesiology, Albany, NY.

Address correspondence: Laxmaiah Manchikanti, MD 2831 Lone Oak Road

Paducah, Kentucky 42003

E-mail:drlm@thepainmd.com

Disclaimer: There was no external funding in the preparation of this manuscript.

Conflict of interest: None.

Manuscript received on: 10/17/2008

Accepted for publication: $11 / 7 / 2008$

Free full manuscript: www.painphysicianjournal.com
Background: Intervertebral discs, facet joints, ligaments, fascia, muscles, and nerve root dura have been described as tissues capable of transmitting pain in the low back. The pathophysiology of spinal radicular pain is the subject of ongoing research and controversy with discogenic pain assuming a major role as a cause of non-specific low back pain. Even though epidural injections are frequently administered in managing axial low back pain, the evidence is lacking.

Study Design: A randomized, double-blind, equivalence trial.

Setting: An interventional pain management practice, a specialty referral center, a private practice setting in the United States.

Objectives: To evaluate the effectiveness of caudal epidural injections with or without steroids in managing chronic low back pain without disc herniation or radiculitis in providing effective and longlasting pain relief and to evaluate the differences between local anesthetic with or without steroids.

Methods: Patients were randomly assigned to one of 2 groups, Group I patients received caudal epidural injections with local anesthetic (lidocaine 0.5\%), whereas Group II patients received caudal epidural injections with $0.5 \%$ lidocaine $9 \mathrm{~mL}$ mixed with $1 \mathrm{~mL}$ of steroid

Randomization was performed by computer-generated random allocation sequence by simple randomization.

Outcomes Assessment: Multiple outcome measures were utilized which included the Numeric Rating Scale (NRS), the Oswestry Disability Index 2.0 (ODI), employment status, and opioid intake with assessment at 3 months, 6 months, and 12 months post-treatment.

Significant pain relief was defined as $50 \%$ or more, whereas significant improvement in disability score was defined as reduction of $40 \%$ or more.

Results: Significant pain relief ( $\geq 50 \%$ ) was demonstrated in $72 \%$ to $81 \%$ of patients and functional status improvement was demonstrated by a reduction of $40 \%$ in the ODI scores in $81 \%$ of the patients. The overall average procedures per year were $3.6 \pm 1.05$ in Group I and $3.9 \pm 1.33$ in Group II with an average total relief per year of $32.3 \pm 16.93$ weeks in Group I and $30.7 \pm 17.94$ weeks in Group II over a period of 52 weeks.

Limitations: The results of this study are limited by lack of a placebo group and a preliminary report of 36 patients in each group.

Conclusion: Caudal epidural injections with or without steroids may be effective in patients with chronic function-limiting low back pain without facet joint pain, disc herniation, and/or radiculitis in over $70 \%$ of the patients.

Key words: Chronic low back pain, caudal epidural injections, discogenic pain, disc herniation, radiculitis, local anesthetic, steroids, controlled comparative local anesthetic blocks, provocation discography CLINICAL TRIAL: NCT00370799

Pain Physician 2008; 11:6:785-800 
K uslich et al (1) identified intervertebral discs, facet joints, ligaments, fascia, muscles, and nerve root dura as tissues capable of transmitting pain in the low back. The first to create widespread interest in the disc as a source of pain in American literature were Mixter and Barr (2) with their 1934 hallmark description of the herniated nucleus pulposus. However, soon after, the report of Mixter and Ayers (3) in 1935, demonstrated that radicular pain can occur without disc herniation. Subsequently, numerous investigators (4-13) have described pain syndromes emanating from lumbar intervertebral disc without mechanically compressing neural structures. The pathophysiology of spinal radicular pain is the subject of ongoing research and controversy and discogenic pain has assumed a major role as a cause of non-specific low back pain, beyond the more specific disc herniation.

Modern technology including magnetic resonance imaging (MRI), computed tomography (CT) axial scanning, neurophysiologic testing, and comprehensive physical examination with psychological evaluation, can identify the cause of low back pain in only $15 \%$ of patients in the absence of disc herniation and neurological deficit (14-17). However, utilizing controlled diagnostic blocks, the prevalence of pain due to internal disc disruption was reported to be $39 \%$ in patients suffering with chronic low back pain (6), whereas primary discogenic pain was reported in $26 \%$ (5) when no other cause was suspected. Further, facet joint pain has been shown to be present in $15 \%$ to $45 \%$ of patients $(5,18$ 23), whereas sacroiliac joint pain has been established in $10 \%$ to $18.5 \%$ of the population $(5,24)$. In a study by Manchikanti et al (5) of the relative contributions of various structures in patients with chronic low back pain who failed to respond to conservative modalities of treatments with lack of radiological evidence to indicate disc protrusion or radiculopathy, $40 \%$ of the patients were shown to have facet joint pain, $26 \%$ discogenic pain, $2 \%$ sacroiliac joint pain, and possibly $13 \%$ segmental dural/nerve root pain with lack of identification of cause in $19 \%$ of the patients. Consequently, approximately $58 \%$ of patients either with discogenic pain, segmental dural nerve root pain, or non-identifiable cause may respond to epidural injections.

Epidural injections for managing chronic low back pain are one of the most commonly performed interventions in the United States (25-27). Friedly et al (28) reported administration of epidural injections in $36 \%$ of patients with axial low back pain. However, there is no clinical evidence for the use of epidural injections in axial low back pain and most recommendations are limited to radicular pain with disc herniation (29-31) except for 2 observational studies utilizing caudal approach $(32,33)$ and one utilizing interlaminar approach (34). Thus, epidural steroid injections are not only the most commonly used procedures in interventional pain management, but also the most contentious and misunderstood modality of treatment $(13,29-31)$.

Multiple approaches available to access the epidural space in the lumbosacral spine include interlaminar, transforaminal, and caudal. The overall effectiveness of epidural steroid injections has been highly variable. The evidence for caudal epidural injections $(13,29,30)$ is Level I in managing pain secondary to disc herniation and radiculitis, whereas in managing axial low back pain the evidence is limited.

Two prospective observational studies have shown significant improvement with caudal epidural injections with or without steroids in patients with chronic low back pain $(32,33)$. Manchikanti et al $(32)$ evaluated the effectiveness of caudal epidural injections in positive and negative chronic low back pain patients after they had failed to show evidence of facet joint pain. They studied 62 patients with the results showing that there was significant improvement in patients receiving caudal epidural injections, with a decrease in pain associated with improved physical, functional, and mental status, decreased opioid intake, and increased return to work. In another study, Manchikanti et al (33) evaluated 65 patients who underwent diagnostic facet joint nerve blocks utilizing controlled comparative local anesthetic block and were found to be negative for facet joint pain and other problems such as sacroiliac joint pain. The results showed that there was significant improvement in patients receiving caudal epidural injections, with a decrease in pain associated with improved physical, functional, and mental status along with return to work. Butterman (34) also evaluated the effect of spinal steroid injections for degenerative disc disease utilizing either interlaminar or transforaminal injections in patients with chronic low back pain of more than one year's duration in a prospective evaluation over a period of 4 years. They reported the effectiveness of epidural steroid injections in improving pain and function at 3 month follow-up. However, at subsequent follow-up periods, the success rate declined. In this study, 1-3 procedures were administered rather than repeating them based on the return of pain. 
This study was undertaken to evaluate the role of caudal epidural injections in patients with chronic low back pain without disc herniation or radiculitis, and negative for facet joint pain by means of controlled comparative local anesthetic blocks. The study is designed to evaluate 120 patients. This preliminary report includes 72 patients completing one-year follow-up.

\section{Methods}

The study was conducted in an interventional pain management practice, a specialty referral center, in a private practice setting in the United States. The study was performed based on Consolidated Standards of Reporting Trials (CONSORT) guidelines and an extension of the CONSORT statement reporting of non-inferiority and equivalence randomized trials (35-37). The study protocol was approved by the Institutional Review Board (IRB) and registered on the U.S. Clinical Trial Registry with an assigned number of NCT00370799.

\section{Participants}

Patients were assigned to one of 2 groups, with Group I patients receiving caudal epidural injections with injection of local anesthetic (lidocaine $0.5 \%$ ), whereas Group II patients received caudal epidural injections with $0.5 \%$ lidocaine $9 \mathrm{~mL}$ mixed with $1 \mathrm{~mL}$ of steroid. Each injection was a total volume of $10 \mathrm{~mL}$ (10 $\mathrm{mL}$ of lidocaine $0.5 \%$ or $9 \mathrm{~mL}$ of lidocaine with $1 \mathrm{~mL}$ of steroid), followed by $2 \mathrm{~mL}$ of $0.9 \%$ sodium chloride solution as a flush.

\section{Interventions}

All patients were provided with the IRB-approved protocol and the informed consent which described in detail all aspects of the study and the withdrawal process.

\section{Pre-Enrollment Evaluation}

The pre-enrollment evaluation included the exclusion of facet joint pain by controlled comparative local anesthetic blocks. Additional information included demographic data, medical and surgical history with co-existing disease(s), radiologic investigations, physical examination, pain rating scores using the Numeric Rating Scale (NRS), work status, opioid intake, and functional status assessment by Oswestry Disability In$\operatorname{dex} 2.0$ (ODI).

All patients without evidence of disc herniation or radiculitis, but with chronic low back pain were evaluated and included in the study. The diagnosis was based on controlled facet joint nerve blocks to exclude patients with lumbar facet joint pain which was suspected based on historical, clinical, and radiological evaluations. Only patients with non-specific low back pain with a duration of at least 6 months were included. Patients with disc herniation with or without radicular symptoms were excluded.

\section{Inclusion Criteria}

Inclusion criteria were a negative diagnosis of lumbar facet joint pain by means of controlled comparative local anesthetic blocks; patients over the age of 18 years; patients with a history of chronic function-limiting low back pain of at least 6 months duration; and patients who were competent to understand the study protocol and provide voluntary, written informed consent and participate in outcome measurements.

Inclusion criteria also included that there was no evidence of disc herniation and patients also had undergone and failed to show positive response to facet joint nerve blocks and also had failed to improve substantially with conservative management including but not limited to physical therapy, chiropractic manipulation, exercises, drug therapy, and bedrest.

Exclusion criteria were a positive response to controlled comparative local anesthetic blocks, previous lumbar surgery, uncontrollable or unstable opioid use, uncontrolled psychiatric disorders, uncontrolled medical illness either acute or chronic, any conditions that could interfere with the interpretation of the outcome assessments, pregnant or lactating women, and patients with a history or potential for adverse reaction(s) to local anesthetics or steroids.

\section{Description of Interventions}

All patients were treated with controlled comparative local anesthetic facet joint nerve blocks. The process started with diagnostic facet joint nerve blocks with $0.5 \mathrm{~mL}$ of $1 \%$ lidocaine, followed by blockade of facet joint nerves with $0.25 \%$ bupivacaine on separate occasions. If they were lidocaine-positive, a response was considered negative, if pain relief lasted less than 2 hours following the lidocaine injection, and lasted less then 3 hours or less than the duration of relief with lidocaine when bupivacaine was used. Controlled, comparative local anesthetic blocks were also performed for sacroiliac joint pain.

All caudal epidural procedures were performed by one physician in an ambulatory surgery setting, 
in a sterile operating room, under fluoroscopy, with patients in the prone position, under appropriate monitoring with intravenous access and sedation with midazolam and fentanyl. With sterile preparation, access to the epidural space was obtained, which was confirmed by injection of non-ionic contrast. Following this, injection of $10 \mathrm{~mL}$ of lidocaine hydrochloride $0.5 \%$ preservative free, or $9 \mathrm{~mL}$ of lidocaine mixed with $6 \mathrm{mg}$ of betamethasone (either brand name or non-particulate) or $40 \mathrm{mg}$ of methylprednisolone was carried out, followed by injection of $2 \mathrm{~mL}$ of $0.9 \%$ sodium chloride solution.

Repeat caudal epidural injections were provided based on the response to prior caudal epidural injections evaluated by improvement in physical and functional status. Further, repeat caudal epidural injections were performed only when increased levels of pain were reported with deteriorating relief below $50 \%$.

\section{Additional Interventions}

All patients underwent the treatments as assigned. A patient was unblinded on request or if an emergency situation existed. If a patient required additional caudal epidural injections, these were provided based on the response to previous injection, either after unblinding or without unblinding. If the patient chose not to be unblinded, the prior treatment was repeated as assigned. However, if patients chose to be unblinded, they were offered either the assigned treatment or another treatment based on their response. If the patients were non-responsive and different treatments other than caudal epidural injections were required, they were considered to be withdrawn from the study, and no subsequent data were collected. However, patients who were non-responsive and continued with conservative management were followed without further epidural injections with medical management, unless they requested unblinding. In addition, all patients who were lost to follow-up were considered withdrawn. Patients unavailable for follow-up were considered as lost-to-follow-up.

\section{Co-Interventions}

Most patients were receiving opioid and non-opioid analgesics, adjuvant analgesics, and some were involved in a therapeutic exercise program. If patients were improving significantly and the medical necessity for these drugs was lacking, medications were stopped or dosages were decreased. In addition, dos- ages were also increased, based on medical necessity. All patients continued previously directed exercise programs, as well as their work. Thus, in this study, there was no specific physical therapy, occupational therapy, bracing, or other interventions offered other than the study intervention.

\section{Objectives}

The study was designed to evaluate the effectiveness of caudal epidural injections with or without steroids in managing chronic low back pain without disc herniation or radiculitis in providing effective and long-lasting pain relief and to evaluate the differences between local anesthetic with or without steroid.

\section{Outcomes}

Multiple outcome measures were utilized which included the NRS (0-10 scale) pain scale, the ODI on a 0-50 scale, employment status, and opioid intake in terms of morphine equivalents with assessment at 3 months, 6 months, and 12 months post-treatment. NRS represented no pain with a 0 and the worst pain imaginable with a 10 . The ODI was utilized for functional assessment. The value and validity of the NRS and ODI have been reported $(37,38)$. Thresholds for the minimum clinical important difference for the ODI varied from a 4 to 15 point change from a total score of 50. Significant pain relief was described as $50 \%$ or more reduction in NRS from baseline, whereas significant improvement and function was described as at least a $40 \%$ reduction in the ODI (39-41).

Based on the dosage frequency and schedule of the drug, the opioid intake was converted into morphine equivalents (42).

Employment and work status were determined based on employability at the time of enrollment rather than including all the patients in the study as employable. Employment and work status were classified into multiple categories such as employable, housewife with no desire to work outside, retired, or over the age 65. Patients who were unemployed due to pain or employed but on sick leave or laid off were considered as employable.

The epidurals were considered to be successful if a patient obtained consistent relief with the first and second procedures of at least one and 3 weeks and if the relief from the second injection outlasted the first injection. All others were considered to be failures. 


\section{Sample Size}

Sample size is calculated based on reduction of NRS. A minimal clinical difference change of 1.2 (d) was set from a previous study (33). With standard deviation $(\sigma)$ of the NRS of $1.5, \delta=d / \sigma, \delta=0.80$, to achieve an alpha of 0.05 and beta of 0.20 with $80 \%$ power (43), it required 26 patients in each group of the trial, allowing for $10 \%$ attrition/non-compliance rate, 58 subjects were required.

Previous studies of interventional techniques have identified 50 to 60 patients as acceptable $(39-41,44)$.

\section{Randomization}

From a total of 120 patients, 60 patients were randomly assigned into each group.

\section{Sequence Generation}

Randomization was performed by computergenerated random allocations sequence by simple randomization.

\section{Allocation Concealment}

The operating room nurse assisting with the procedure randomized the patients and prepared the drugs appropriately.

\section{Implementation}

Participants were invited to enroll in the study if they met inclusion criteria. One of the 3 nurses assigned as coordinators of the study enrolled the participants and assigned participants to their respective groups.

\section{Blinding (Masking)}

Participants and those administering the interventions were blinded to group assignment. The blinding was assured by mixing the patients with other patients receiving routine treatment and not informing the physician performing the procedure the inclusion of the patients in the study. All the patients for one-year follow-up were selected by the statistician not participating in provision of patient care. The unblinding results were not disclosed to either the treating physician or other participants or patients. Thus, the nature of blinding was not interrupted.

\section{Statistical Methods}

Statistical analysis included chi-squared statistic, Fisher's exact test, t-test, and paired t-test. Results were considered statistically significant if the $P$ value was less than 0.05 .

Chi-squared statistic was used to test the differences in proportions. Fisher's exact test was used wherever the expected value was less than 5; a paired t-test was used to compare the pre- and post-treatment results of average pain scores and ODI measurements at baseline versus 3 months, 6 months, and 12 months. For comparison of mean scores between groups, t-test was performed.

\section{Intent-to-Treat-Analysis}

An intent-to-treat-analysis was performed. Either the last follow-up data or initial data were utilized in the patients who dropped out of the study and no other data were available.

\section{Results}

\section{Participant Flow}

Figure 1 illustrates the participant flow.

\section{Recruitment}

The recruitment period lasted from January 2007 to August 2008.

\section{Baseline Data}

Baseline demographic and clinical characteristics of each group are illustrated in Table 1. There were no significant differences noted between the groups.

\section{Analysis of Data}

\section{Numbers Analyzed}

A schematic illustration of patient flow is provided in Fig. 1. The study period for one-year follow-up lasted from January 2007 to August 2008 with completion of one-year follow-up of 72 patients with 36 patients in each group. In Group II, 12 patients each received non-particulate Celestone, brand-name Celestone, or Depo-Medrol. The data were available in the majority of the included patients. Intent-to-treat analysis was performed due to non-available data on 10 occasions in Group I on a total of 7 patients, and on 5 occasions on 3 patients in Group II. Based on the number of treatments provided, lack of follow-up was found in 10 of 108 occasions (9.3\%) in Group I or 7 of 36 patients (19.4\%); whereas it was 5 of $108(4.6 \%)$ occasions in Group II with 3 of 36 patients (8.3\%) at least one time. 


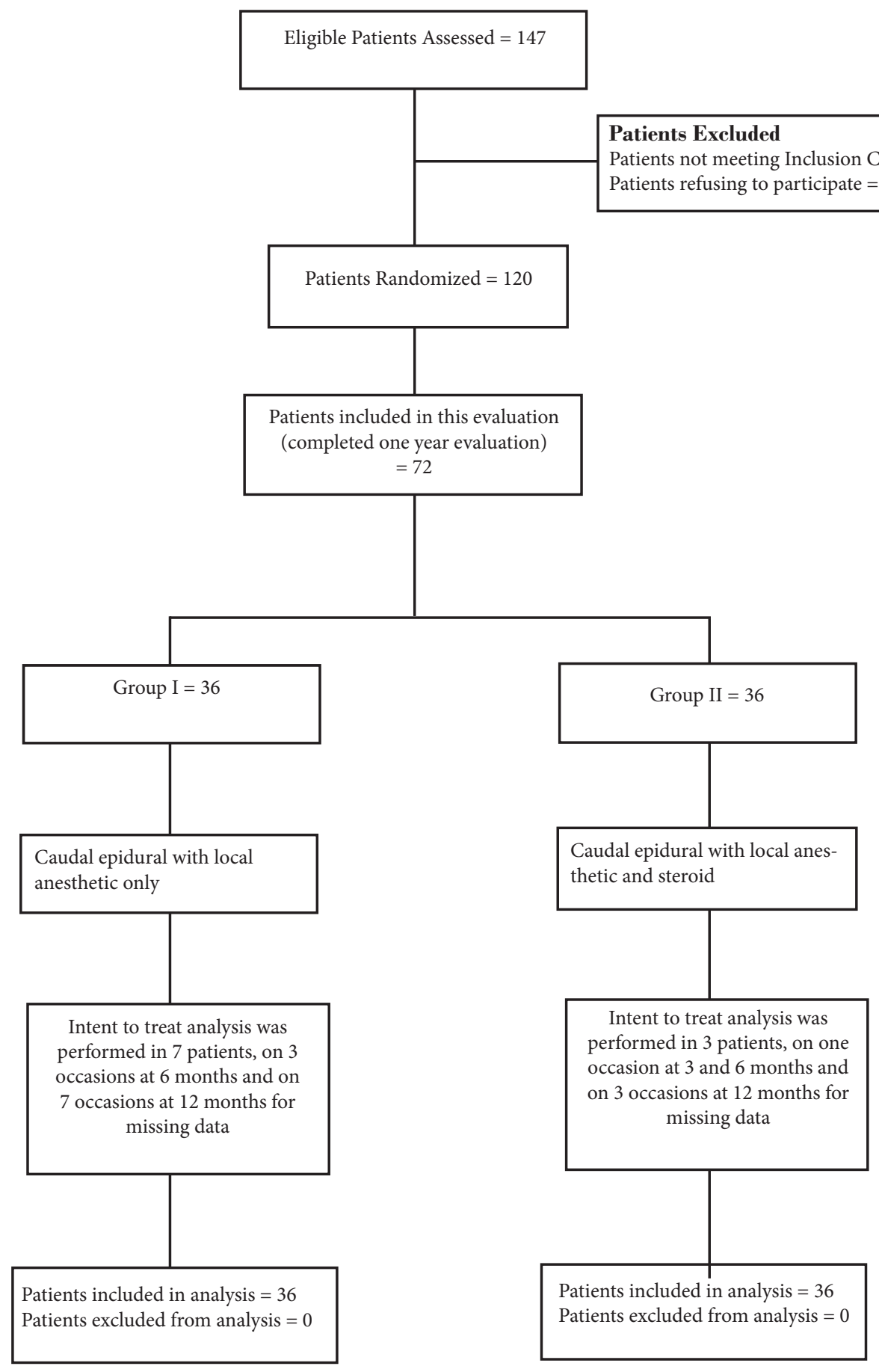

Fig. 1. Flow diagram of selection process of literature. 
Table 1. Baseline demographic and clinical characteristics of participants.

\begin{tabular}{|c|c|c|c|c|}
\hline & & $\begin{array}{c}\text { Group } 1 \\
(n=36)\end{array}$ & $\begin{array}{c}\text { Group II } \\
(\mathbf{n}=\mathbf{3 6})\end{array}$ & P value \\
\hline \multirow{2}{*}{ Gender } & Male & $33 \%(12)$ & $47 \%(17)$ & \multirow{2}{*}{0.337} \\
\hline & Female & $67 \%(24)$ & $53 \%(19)$ & \\
\hline Age & Mean \pm SD & $48.7 \pm 15.80$ & $43.2 \pm 13.34$ & 0.117 \\
\hline Weight & Mean \pm SD & $195 \pm 61.71$ & $188 \pm 41.3$ & 0.577 \\
\hline Height & Mean \pm SD & $66 \pm 3.95$ & $67 \pm 3.90$ & 0.355 \\
\hline Duration of Pain & Mean \pm SD & $94 \pm 68.87$ & $108 \pm 99.38$ & 0.486 \\
\hline \multirow{2}{*}{ Onset of the Pain } & Gradual & $69 \%(25)$ & $67 \%(24)$ & \multirow{2}{*}{1.000} \\
\hline & Injury & $31 \%(11)$ & $33 \%(12)$ & \\
\hline \multirow{2}{*}{ Low Back Pain Distribution } & Bilateral & $81 \%(29)$ & $83 \%(30)$ & \multirow{2}{*}{1.000} \\
\hline & Left or right & $19 \%(7)$ & $17 \%(6)$ & \\
\hline Numeric Pain Rating Score & Mean \pm SD & $7.9 \pm 0.82$ & $7.9 \pm 1.05$ & 0.901 \\
\hline Oswestry Disability Index & Mean \pm SD & $26.9 \pm 5.15$ & $27.9 \pm 4.96$ & 0.417 \\
\hline
\end{tabular}

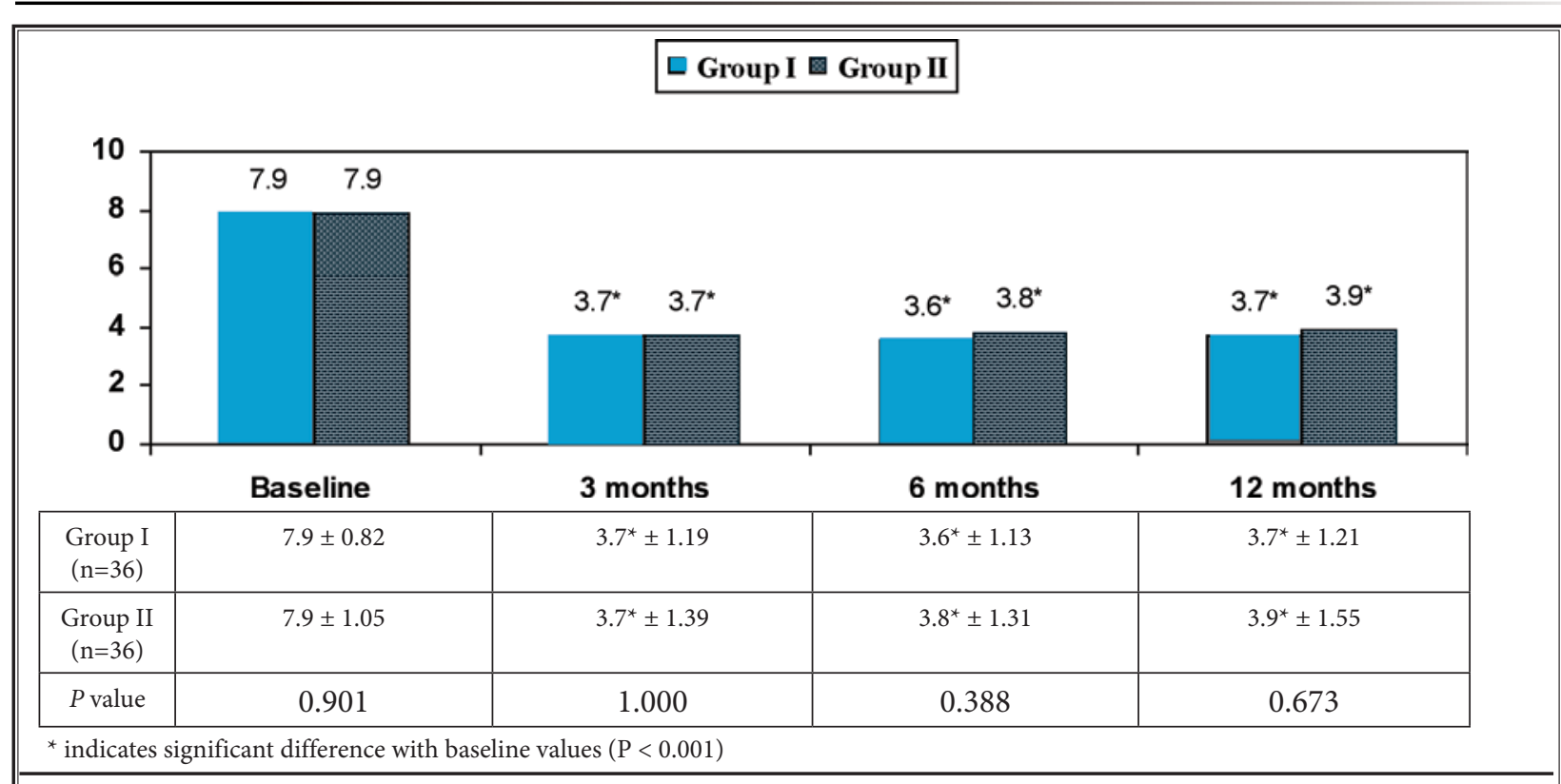

Fig. 2. Illustration of pain relief characteristics (mean $\pm S D$ ).

\section{Outcomes}

\section{Pain Relief}

Figure 2 illustrates the NRS scores. Pain scores changed significantly from baseline, at 3 months, 6 months, and 12 months in both groups, with no significant differences between the groups or follow-up periods.
The proportion of patients with significant pain relief of $50 \%$ or greater are illustrated in Fig. 3 with $72 \%$ in both groups at 12 months. There were no significant differences between the groups or from the 3-month to 6-month to 12-month outcomes. 


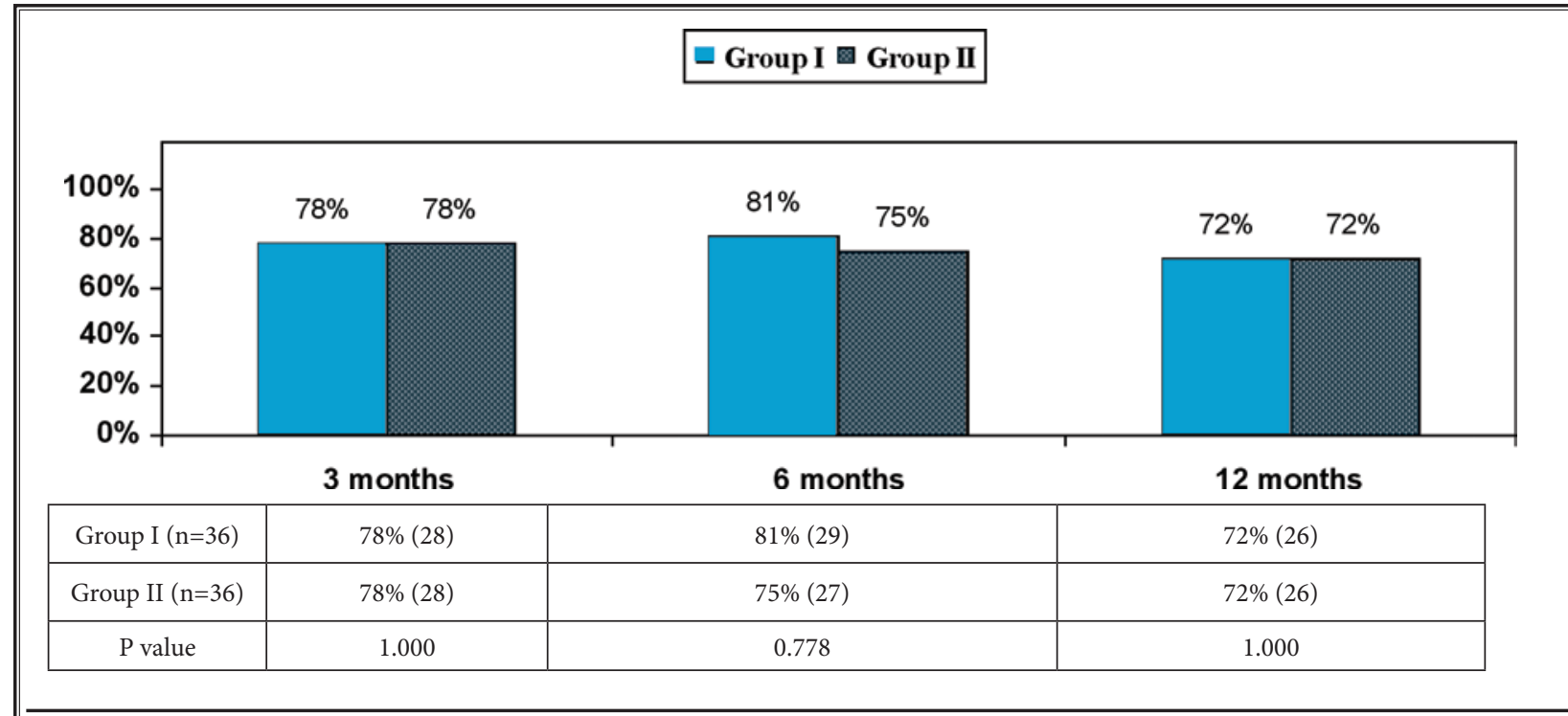

Fig. 3. Illustration of significant pain relief ( $\geq 50 \%$ reduction in Numeric Rating Score from baseline).

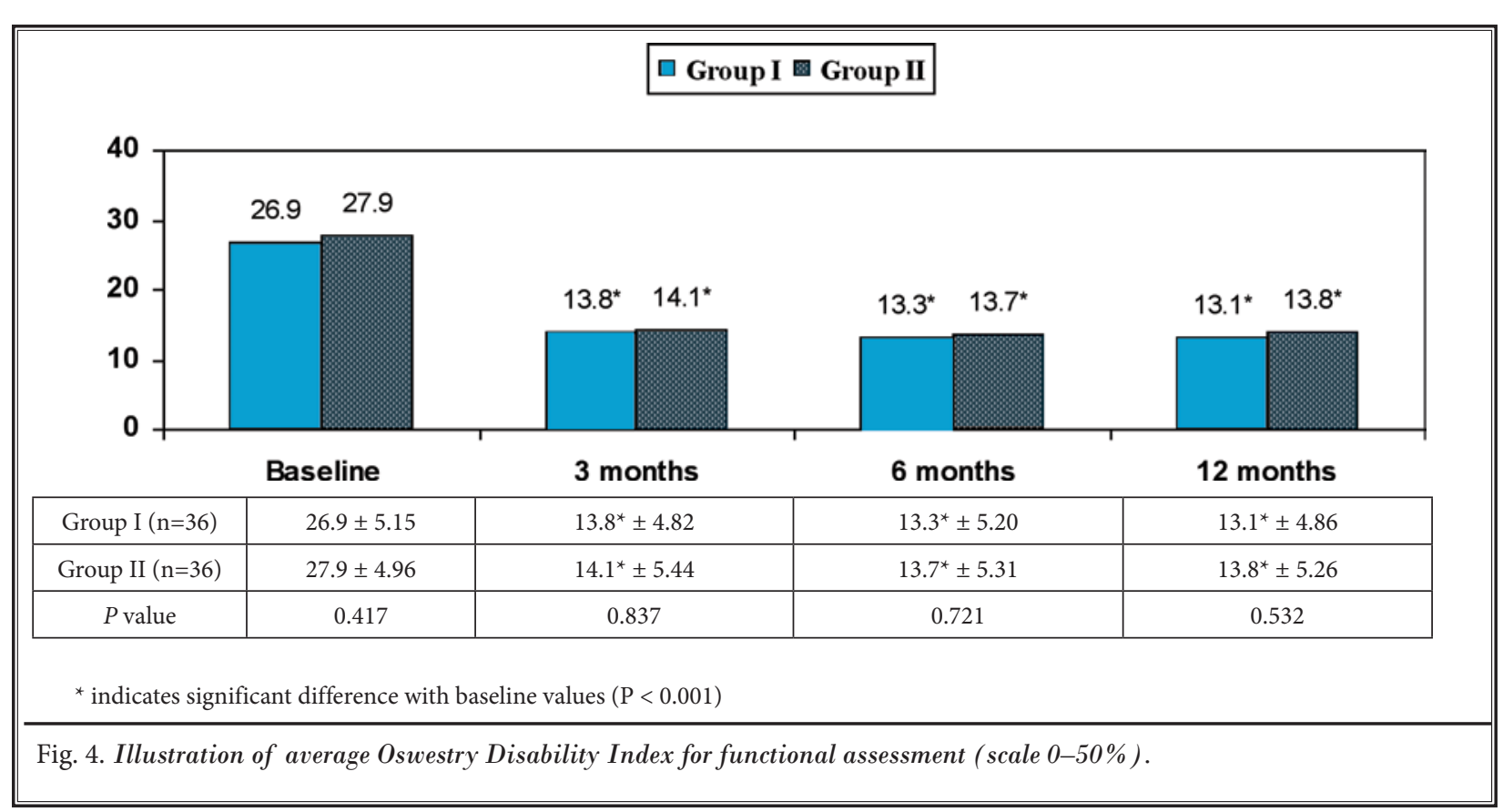

\section{Functional Assessment}

Functional assessment results assessed by the ODI are illustrated in Fig. 4. Significant improvement was seen in the functional status in both groups from baseline to one year. Reduction of Oswestry scores of at least
$40 \%$ was seen in $81 \%$ of the patients at 3 months, 6 months, and 12 months in both groups, of the patients as shown in Fig. 5 with no significant differences noted between the groups or during follow-up periods. 


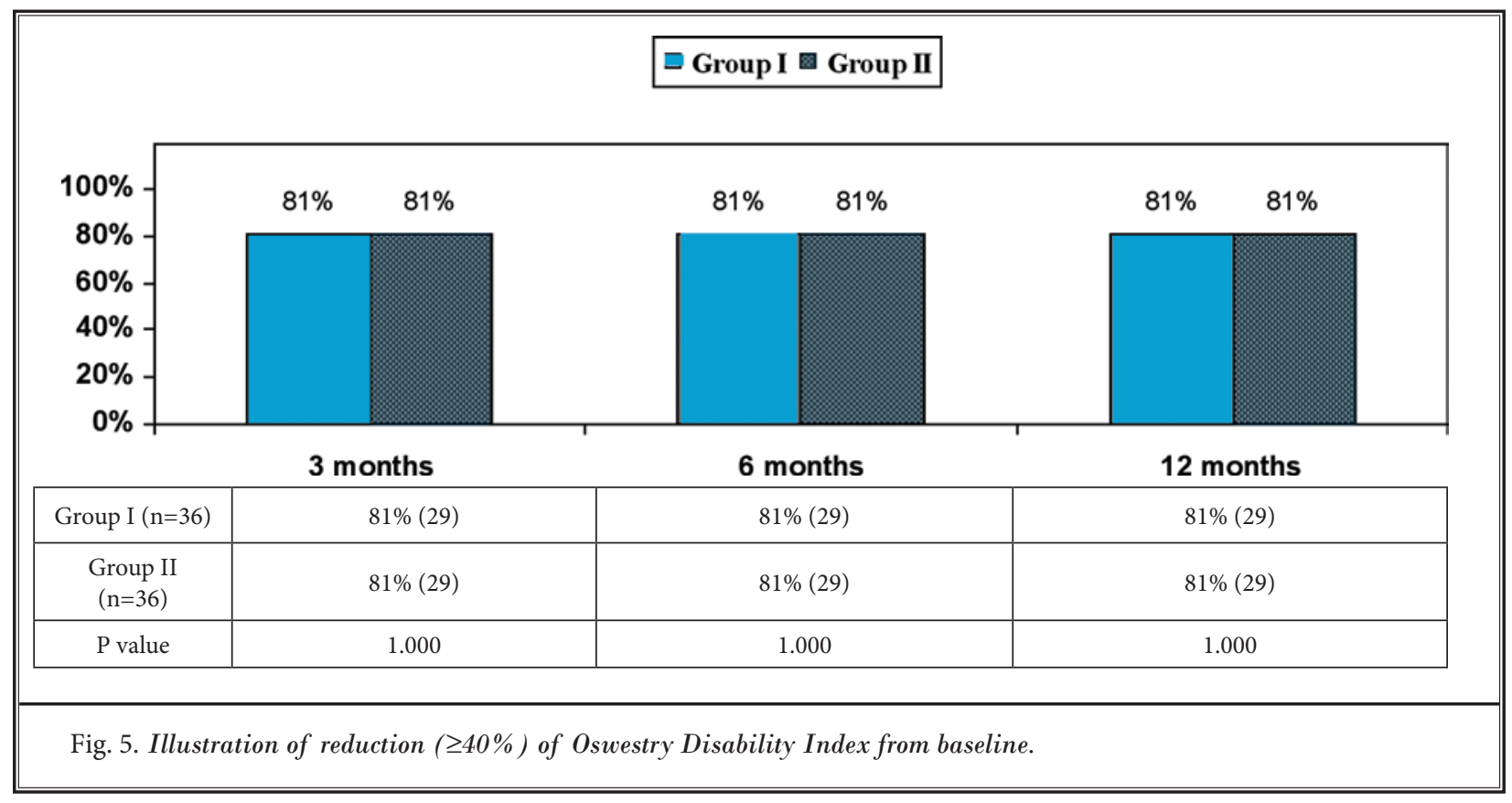

Table 2. Employment characteristics.

\begin{tabular}{|l|c|c|c|c||}
\hline \multirow{2}{*}{ Employment status } & \multicolumn{2}{|c|}{ Group I } & \multicolumn{2}{|c|}{ Group II } \\
\cline { 2 - 5 } & Baseline & 12 months & Baseline & 12 months \\
\hline Employed part-time & 0 & 0 & 2 & 3 \\
\hline Employed full-time & 5 & 9 & 6 & 2 \\
\hline Unemployed/laid off/sick & 6 & 2 & 8 & 11 \\
\hline Total Employed & 5 & 9 & $\mathbf{1 4}$ & $\mathbf{1 3}$ \\
\hline Eligible for employment & $\mathbf{1 1}$ & 4 & 3 & 3 \\
\hline Housewife with no desire to work outside & 4 & 17 & 18 & 19 \\
\hline Disabled & 17 & 4 & $\mathbf{3 6}$ & 1 \\
\hline Over 65 year of age & 4 & $\mathbf{3 6}$ & $\mathbf{3 6}$ \\
\hline Total Number of Patients & $\mathbf{3 6}$ & & \\
\hline
\end{tabular}

\section{Employment Characteristics}

Table 2 demonstrates employment characteristics in both groups. At baseline, there were 11 patients eligible for employment in Group I and 14 patients eligible in Group II, whereas the number of patients eligible for employment remained the same at 12 months in Group I and reduced to 13 in Group II. Of these, there were 5 patients employed in Group I and 8 in Group II which increased to 9 of 11 employable in Group I and 11 of 13 employable in Group II.

\section{Opioid Intake}

Table 3 illustrates opioid intake between both groups at baseline and at 12 months that showed no significant change in intake of opioids. However, opioid intake significantly decreased from their baseline opioid intake in both groups at 12 months.

\section{Therapeutic Procedural Characteristics}

Therapeutic procedural characteristics with average pain relief per procedure are illustrated in Table 
Table 3. Opioid intake based on morphine equivalents in milligrams.

\begin{tabular}{|c|c|c|c|}
\hline \multirow[t]{2}{*}{ Opioid intake } & $\begin{array}{c}\text { Group I } \\
(\mathrm{n}=36)\end{array}$ & Group II $(n=36)$ & \multirow[t]{2}{*}{ P value between groups } \\
\hline & Mean \pm SD & Mean \pm SD & \\
\hline Baseline & $41.4 \pm 38.08$ & $46.4 \pm 23.84$ & 0.504 \\
\hline 3 months & $31.2 \# \pm 29.93$ & $34.7 \# \pm 22.79$ & 0.575 \\
\hline 6 months & $30.9 \# \pm 30.08$ & $38.5 \pm 38.10$ & 0.354 \\
\hline 12 months & $30.9 \# \pm 30.08$ & $35.3 \# \pm 22.57$ & 0.486 \\
\hline
\end{tabular}

\# indicates significant difference with baseline values $(P<0.05)$

Table 4. Illustration of procedural characteristics with procedural frequency, average relief per procedure, and average total relief in weeks over a period of one-year.

\begin{tabular}{|c|c|c|c|c|c|c|}
\hline & \multicolumn{2}{|c|}{ Successful group } & \multicolumn{2}{|c|}{ Failed group } & \multicolumn{2}{|c|}{ Overall } \\
\hline & $\begin{array}{l}\text { Group I } \\
(n=25)\end{array}$ & $\begin{array}{c}\text { Group II } \\
(\mathbf{n}=\mathbf{2 5})\end{array}$ & $\begin{array}{l}\text { Group I } \\
(n=11)\end{array}$ & $\begin{array}{c}\text { Group II } \\
(\mathrm{n}=11)\end{array}$ & $\begin{array}{l}\text { Group I } \\
(\mathrm{n}=36)\end{array}$ & $\begin{array}{c}\text { Group II } \\
(n=36)\end{array}$ \\
\hline 1st injection relief & $\begin{array}{l}7.1 \pm 7.40 \\
(25)\end{array}$ & $\begin{array}{l}6.2 \pm 3.50 \\
(25)\end{array}$ & $\begin{array}{l}2.6 \# \pm 2.11 \\
\quad(11)\end{array}$ & $\begin{array}{l}0.7 \pm 1.56 \\
\quad(11)\end{array}$ & $\begin{array}{c}5.7 \pm 6.56 \\
(36)\end{array}$ & $\begin{array}{l}4.6 \pm 3.96 \\
(36)\end{array}$ \\
\hline 2nd injection relief & $\begin{array}{l}12.6 \# \pm 5.76 \\
(25)\end{array}$ & $\begin{array}{l}9.1 \pm 3.63 \\
\quad(25)\end{array}$ & $\begin{array}{c}0.9 \pm 0.99 \\
(10)\end{array}$ & $\begin{array}{l}1.5 \pm 1.41 \\
(8)\end{array}$ & $\begin{array}{l}9.3 \pm 7.2 \\
(35)\end{array}$ & $\begin{array}{l}7.2 \pm 4.6 \\
(33)\end{array}$ \\
\hline 3rd injection relief & $\begin{array}{l}12.6 \pm 5.19 \\
(22)\end{array}$ & $\begin{array}{l}11.1 \pm 3.22 \\
\quad(23)\end{array}$ & $\begin{array}{c}4.6 \pm 3.96 \\
(8)\end{array}$ & $\begin{array}{c}6.2 \pm 4.67 \\
(6)\end{array}$ & $\begin{array}{l}10.5 \pm 6.01 \\
\quad(30)\end{array}$ & $\begin{array}{l}10.1 \pm 4.02 \\
\quad(29)\end{array}$ \\
\hline 4 th injection relief & $\begin{array}{l}13.0 \pm 4.14 \\
\quad(16)\end{array}$ & $\begin{array}{l}12.1 \pm 1.80 \\
\quad(21)\end{array}$ & $\begin{array}{l}7.6 \pm 6.11 \\
(5)\end{array}$ & $\begin{array}{l}4.4 \pm 5.18 \\
(5)\end{array}$ & $\begin{array}{l}11.7 \pm 5.09 \\
(21)\end{array}$ & $\begin{array}{l}10.6 \pm 4.04 \\
\quad(26)\end{array}$ \\
\hline 5th injection relief & $\begin{array}{l}12.1 \pm 1.46 \\
(7)\end{array}$ & $\begin{array}{l}10.4 \pm 4.19 \\
\quad(12)\end{array}$ & $\begin{array}{c}13.0 \\
(1)\end{array}$ & $\begin{array}{c}12.0 \pm 1.41 \\
(2)\end{array}$ & $\begin{array}{c}12.3 \pm 1.39 \\
(8)\end{array}$ & $\begin{array}{l}10.6 \pm 3.91 \\
\quad(14)\end{array}$ \\
\hline $\begin{array}{l}\text { Number of injections per } \\
\text { year }\end{array}$ & $\begin{array}{l}3.8 \pm 0.96 \\
\quad(25)\end{array}$ & $\begin{array}{l}4.2 \pm 0.92 \\
\quad(25)\end{array}$ & $\begin{array}{l}3.2 \pm 1.17 \\
\quad(11)\end{array}$ & $\begin{array}{l}3.0 \pm 1.73 \\
(11)\end{array}$ & $\begin{array}{l}3.6 \pm 1.05 \\
\quad(36)\end{array}$ & $\begin{array}{l}3.9 \pm 1.33 \\
\quad(36)\end{array}$ \\
\hline Total relief per year (weeks) & $\begin{array}{l}41.5 \pm 8.48 \\
(25)\end{array}$ & $\begin{array}{l}40.4 \pm 10.24 \\
\quad(25)\end{array}$ & $\begin{array}{l}11.4 \pm 11.8 \\
(11)\end{array}$ & $\begin{array}{l}8.6 \pm 10.35 \\
(11)\end{array}$ & $\begin{array}{l}32.3 \pm 16.93 \\
(36)\end{array}$ & $\begin{array}{l}30.7 \pm 17.94 \\
\quad(36)\end{array}$ \\
\hline
\end{tabular}

\# indicates significant difference between groups $(P<0.05)$

4. Average overall relief per year was $32.3 \pm 16.93$ weeks in Group I and $30.7 \pm 17.94$ weeks in Group II with no significant differences. However, when patients were separated into successful and failed groups, the total number of injections per year was $3.8 \pm 0.96$ in Group I and $4.2 \pm 0.92$ in Group II for successful subjects with relief of $41.5 \pm 8.48$ weeks in Group I and $40.4 \pm 10.24$ weeks in Group II. In contrast, in failed subjects the number of injections per year was $3.2 \pm 1.17$ in Group I and $3.0 \pm 1.73$ in Group II with average relief of $11.4 \pm 11.8$ weeks in Group I and $8.6 \pm 10.35$ weeks in Group II.

Epidurals were considered to be successful if a patient obtained consistent relief with the first and second injections of at least one and 3 weeks and the relief with the second injection outlasting the first injection. All others were considered as failures.

\section{Changes in Weight}

There were no significant differences in change (gain or loss) in body weight from baseline in both groups (Table 5).

\section{Adverse Events}

There were no major adverse events reported over a period of one year in 72 patients. 
Table 5. Characteristic weight monitoring.

\begin{tabular}{|c|c|c|c|}
\hline \multirow[t]{2}{*}{ Weight (lbs) } & Group I $(n=36)$ & Group II $(n=36)$ & \multirow{2}{*}{ P value } \\
\hline & Mean \pm SD & Mean \pm SD & \\
\hline Initial weight & $194.8 \pm 61.71$ & $187.8 \pm 41.34$ & 0.577 \\
\hline Weight at one year & $191.6 \pm 59.98$ & $186.3 \pm 42.81$ & 0.669 \\
\hline Change & $-3.2 \pm 9.92$ & $-1.5 \pm 9.99$ & 0.480 \\
\hline Participants with weight loss & $53 \%(19)$ & $53 \%(19)$ & \multirow{3}{*}{0.753} \\
\hline Participants without change & $17 \%(6)$ & $11 \%(4)$ & \\
\hline Participants with weight gain & $30 \%(11)$ & $36 \%(13)$ & \\
\hline
\end{tabular}

\section{Discussion}

Preliminary results of this study of 72 patients showed significant pain relief ( $\geq 50 \%)$ in $72 \%$ of the patients with no significant differences noted with or without steroid over a period of one-year. In addition, functional assessment measured by ODI also showed significant improvement with at least a $40 \%$ reduction in Oswestry scores in $81 \%$ of the patients with no significant differences between the groups. The average procedures per year were $3.6 \pm 1.05$ in Group I and $3.9 \pm 1.33$ in Group II with an average total relief per year of $32.3 \pm 16.93$ weeks in Group I and $30.7 \pm$ 17.94 weeks in Group II over a period of 52 weeks. Further, when patients were separated into successful and failed groups, the total relief per year was 41.5 \pm 8.48 in Group I and $40.4 \pm 10.24$ weeks in Group II among successful subjects with very low response in failed subjects. This study provides modest results with an average relief of 6 to 12 weeks with the first and second procedures in the successful group, with an average relief of 10 to 13 weeks with subsequent procedures.

The results of this study illustrate that if the response is fair to poor with the first 2 injections, they will continue to exhibit poor response with future treatments. The opioid intake was also reduced in both groups at one-year follow-up. While the results of employment are not significant, the pain relief and improvement in functional status are significant. Strict criteria were incorporated into the study and the patients only judged not to have facet joint pain were included in the study, thus avoiding the criticism of including patients with facet joint pain in the study contributing to the negative results.

There is significant controversy with regards to medical necessity and indications of lumbar epidural injections either by interlaminar approach or caudal approach. Multiple systematic reviews, guidelines, and other reviews have identified indications for caudal epidural injections in positive reports to treat radicular pain from herniated lumbar intervertebral discs. The evidence for other indications is limited. Two prospective evaluations $(32,33)$ have shown positive results in patients without disc herniation or radiculitis, but with chronic function-limiting low back pain. In these studies, patients without facet joint pain were evaluated under fluoroscopy. As illustrated in the present study, epidural injections do not provide long-term relief. However, long-term relief can be achieved with judicious use and appropriate evaluation in patients without facet joint pain, lasting on average, 10 to 13 weeks in the phase after 2 initial injections. These results are similar to the patients receiving caudal epidural injections either with or without steroids with disc herniation and radiculitis (45), but superior to patients suffering with spinal stenosis and post-surgery syndrome $(46,47)$. Finally, the results of this randomized, equivalence trial reinforce and validate the previous findings in prospective evaluations.

The results of this evaluation are generalizable to interventional pain management settings with appropriate diagnostic techniques and under fluoroscopic visualization. Since this is an equivalence trial, it is also considered a practical clinical trial. The results of this study are applicable to individual patients or groups that differ from those controlled in the placebo trials. In the era of evidence-based medicine, pragmatic or practical clinical trials measuring effectiveness are considered more appropriate than explanatory trials measuring efficacy $(37,48-52)$. Explanatory trials measure efficacy, whereas pragmatic or practical trials are best designed to provide the results of benefit of the treatment produced in routine clinical practice. In ad- 
dition, in this study the evidence is based on head-tohead comparisons of clinically relevant alternatives - namely local anesthetic with or without steroids. A placebo-controlled trial measures absolute effect size and shows existence of effect. In contrast, an active control trial such as the present study not only shows the existence of effect, but also compares therapies (53).

The study may be criticized for the lack of placebo group and preliminary analysis. However, considering the difficulties related to placebo groups in interventional techniques in the United States, the present study with local anesthetics with or without steroid is appropriate. Further, even though it is a preliminary analysis, the number of patients included in this analysis exceeds the sample size calculation of 58 subjects.

The issue of lack of a placebo group is addressed in pragmatic trials with a treatment response accounting for the total difference between 2 treatments, including both treatment as well as associated placebo effects, thus, this provides internal validity. This study may resolve to some extent the issue of the local anesthetics with or without steroids in managing chronic function-limiting low back pain without disc herniation, radiculitis, or facet joint pain. These results describe patients in a private practice, interventional pain management setting in a practical and pragmatic clinical trial. Consequently, the results are not applicable in the general population unless the same methodology is utilized with the diagnosis and therapy. Further, generalizability of the findings of this study may only be feasible in studies utilizing larger populations in multiple settings.

The underlying mechanism of action of epidurally administered steroid and local anesthetic injection is still not well understood. It is believed that the achieved neural blockade alters or interrupts nociceptive input, reflex mechanism of the afferent fibers, self-sustaining activity of the neurons, and the pattern of central neuronal activities $(13,54,55)$. Further, corticosteroids have been shown to reduce inflammation by inhibiting either the synthesis or release of a number of pro-inflammatory mediators and by causing a reversible local anesthetic effect (54-63). In contrast, local anesthetics have been described to provide short- to long-term symptomatic relief based on various mechanisms (64-76). It has been described that multiple pathophysiologic mechanisms may be involved in chronic pain including noxious peripheral stimulation, excess nociceptive process resulting in the sensitization of the pain pathways at several neuronal levels $(64,65)$, and excess release of neurotransmitters causing complex central responses including hyperalgesia or wind-up (63), resulting in an increase in nociceptive sensitization of the nervous system $(66,67)$, and phenotype changes which are also considered as part of the neuronal plasticity (66-68). Consequently, it has been postulated that local anesthetics may provide analgesia by suppression of nociceptive discharge, the block of axonal transport $(74,75)$, the block of the sympathetic reflex arc $(67,73)$, the block of sensitization $(64,65)$, anti-inflammatory effect $(76)$, and blockade of axonal transport of nerve fibers at lower concentrations compared with those that are necessary for a block of a nerve conduction $(74,75)$. The long-lasting effect of local anesthetics in epidural injections has been demonstrated in a multitude of studies $(32,33,39-41,73,75-85)$. Sato et al (84) evaluated the prolonged analgesic effect of epidural bupivacaine in a rat model of neuropathic pain and concluded that repetitive administration of bupivacaine into the epidural space in rats exerts an analgesic effect, possibly by inducing a plastic change in nociceptive input. Further, Tachihara et al (85) showed in rats that nerve root infiltration prevented mechanical allodynia, however, no additional benefit from using corticosteroid was identified, suggesting that corticosteroid may be unnecessary for nerve root blocks.

Multiple studies have reported that not only mechanical compression due to intervertebral disc protrusion, but also nociceptive and inflammatory mediators originating from the nucleus pulposus, play important roles in the onset of pain in lumbar disc herniation (85-97). Corticosteroids have therapeutic effects on radicular symptoms caused by lumbar disc herniation due to their anti-inflammatory function. Furthermore, corticosteroids reportedly ameliorate early vascular permeability increases in spinal nerve roots and inhibit reductions in nerve conduction velocity induced by epidural application of nucleus pulposus (56). Finally, corticosteroids may exert "anesthetic like" actions on nociceptive $C$ fiber conduction independent of anti-inflammatory properties (98). However, corticosteroids are also known to possess direct neurotoxic effects on peripheral nerve tissue $(55,62,99,100)$ unlike local anesthetics.

Overall, the evidence in this report demonstrates caudal epidural injections in patients negative for lumbar facet joint pain confirmed by controlled, comparative local anesthetic blocks with a criteria of $80 \%$ 
pain relief, which is not sustainable after prior painful movements for appropriate duration of action of local anesthetic, without disc herniation or radiculitis, may be treated with caudal epidural injections with or without steroids, providing approximately 12 weeks of relief with each procedure and requiring 3-4 episodes of treatment per year.

\section{Conclusion}

The assessment of the preliminary results of this randomized, controlled, equivalence trial of caudal epi- dural injections in chronic function-limiting low back pain without facet joint pain, disc herniation, and/or radiculitis demonstrated effectiveness in over $70 \%$ of the patients with improvement in functional status.

\section{Acknowledgments}

The authors wish to thank Sekar Edem for assistance in search of literature and Tonie M. Hatton and Diane E. Neihoff, Transcriptionists, for their assistance in preparation of this manuscript.

\section{References}

1. Kuslich SD, Ulstrom CL, Michael CJ. The tissue origin of low back pain and sciatica: A report of pain response to tissue stimulation during operation on the lumbar spine using local anesthesia. Orthop Clin North Am 1991; 22:181-187.

2. Mixter WJ, Barr JS. Rupture of the intervertebral disc with involvement of the spinal canal. N Eng J Med 1934; 211:210215.

3. Mixter WJ, Ayers JB. Herniation or rupture of the intervertebral disc into the spinal canal. N Engl J Med 1935; 213:385-395.

4. Pang WW, Mok MS, Lin ML, Chang DP, Hwang MH. Application of spinal pain mapping in the diagnosis of low back pain-analysis of 104 cases. Acta Anaesthesiol Sin 1998; 36:71-74.

5. Manchikanti L, Singh V, Pampati V, Damron KS, Barnhill RC, Beyer CD, Cash KA. Evaluation of the relative contributions of various structures in chronic low back pain. Pain Physician 2001; 4:308-316.

6. Schwarzer AC, Aprill CN, Derby R, Fortin J, Kine G, Bogduk N. The prevalence and clinical features of internal disc disruption in patients with chronic low back pain. Spine 1995; 20:1878-1883.

7. Fernstrom U. A discographical study of ruptured lumbar discs. Acta Chirurg Scand 1960; 258:1-60.

8. Hirsch C. An attempt to diagnose level of disc lesion clinically by disc puncture. Acta Orthop Scand 1948; 18:132-140.

9. Lindblom K. Diagnostic puncture of intervertebral disks in sciatica. Acta Orthop Scand 1948; 17:231-239.

10. Crock HV. A reappraisal of intervertebral disc lesions. Med J Aust 1970; 1:983989.
11. Ohnmeiss DD, Vanharanta H, Ekholm J. Degree of disc disruption and lower extremity pain. Spine 1997; 22:16001605.

12. Wheeler AH, Murrey DB. Chronic lumbar spine and radicular pain: Pathophysiology and treatment. Curr Pain Headache Rep 2002; 6:97-105.

13. Boswell MV, Trescot AM, Datta S, Schultz DM, Hansen HC, Abdi S, Sehgal N, Shah RV, Singh V, Benyamin RM, Patel VB, Buenaventura RM, Colson JD, Cordner HJ, Epter RS, Jasper JF, Dunbar EE, Atluri SL, Bowman RC, Deer TR, Swicegood JR, Staats PS, Smith HS, Burton AW, Kloth DS, Giordano J, Manchikanti L. Interventional techniques: Evidencebased practice guidelines in the management of chronic spinal pain. Pain Physician 2007; 10:7-111.

14. Bogduk N, McGuirk B. Causes and sources of chronic low back pain. In Bogduk N, McGuirk B (eds). Medical Management of Acute and Chronic Low Back Pain. An Evidence-Based Approach: Pain Research and Clinical Management, Vol. 13, Elsevier Science BV, Amsterdam, 2002, pp 115-126.

15. Bogduk N, McGuirk B. An algorithm for precision diagnosis. In Bogduk N, McGuirk B (eds). Medical Management of Acute and Chronic Low Back Pain. An Evidence-Based Approach: Pain Research and Clinical Management, Vol. 13. Elsevier Science BV, Amsterdam, 2002, 13:177-186.

16. Carragee EJ. Clinical practice. Persistent low back pain. N Engl J Med 2005; 352:1891-1898.

17. Spitzer WO, LeBlanc FE, Dupuis M. Scientific approach to the assessment and management of activity-related spinal disorders: A monograph for clinicians. Report of Quebec Task Force on Spinal Disorders. Spine 1987; 12:S1-59.

18. Manchikanti L, Boswell MV, Singh V, Pampati V, Damron KS, Beyer CD. Prevalence of facet joint pain in chronic spinal pain of cervical, thoracic, and lumbar regions. BMC Musculoskelet Disord 2004; 5:15.

19. Manchukonda R, Manchikanti KN, Cash KA, Pampati V, Manchikanti L. Facet joint pain in chronic spinal pain: An evaluation of prevalence and false-positive rate of diagnostic blocks. J Spinal Disord Tech 2007; 20:539-545.

20. Schwarzer AC, Aprill CN, Derby R, Fortin J, Kine G, Bogduk N. Clinical features of patients with pain stemming from the lumbar zygapophysial joints. Is the lumbar facet syndrome a clinical entity? Spine 1994; 19:1132-1137.

21. Schwarzer AC, Wang SC, Bogduk N, McNaught PJ, Laurent R. Prevalence and clinical features of lumbar zygapophysial joint pain: A study in an Australian population with chronic low back pain. Am Rheum Dis 1995; 54:100-106.

22. Manchikanti L, Pampati V, Fellows B, Baha AG. The inability of the clinical picture to characterize pain from facet joints. Pain Physician 2000; 3:158-166.

23. Manchikanti L, Manchukonda R, Pampati V, Damron KS, McManus CD. Prevalence of facet joint pain in chronic low back pain in postsurgical patients by controlled comparative local anesthetic blocks. Arch Phys Med Rehabil 2007; 88:449-455.

24. Maigne JY, Aiviliklis A, Pfefer F. Results of sacroiliac joint double block and value of sacroiliac pain provocation test in 
54 patients with low back pain. Spine 1996; 21:1889-1892.

25. Manchikanti L. Medicare in interventional pain management: A critical analysis. Pain Physician 2006; 9:171198.

26. Manchikanti L, Giordano J. Physician payment 2008 for interventionalists: Current state of health care policy. Pain Physician 2007; 10:607-626.

27. Specialty Utilization data files from Centers for Medicare and Medicaid Services. Medicare: www.cms.hhs.gov

28. Friedly J, Leighton C, Deyo R. Increases in lumbosacral injections in the Medicare population: 1994 to 2001. Spine 2007; 32:1754-1760.

29. Manchikanti L, Singh V, Derby R, Schultz DM, Benyamin RM, Prager JP, Hirsch JA. Reassessment of evidence synthesis of occupational medicine practice guidelines for interventional pain management. Pain Physician 2008; 11:393482.

30. Abdi S, Datta S, Trescot AM, Schultz DM, Adlaka R, Atluri SL, Smith HS, Manchikanti L. Epidural steroids in the management of chronic spinal pain: A systematic review. Pain Physician 2007; 10:185-212.

31. Staal JB, de Bie R, de Vet HC, Hildebrandt J, Nelemans P. Injection therapy for subacute and chronic low-back pain. Cochrane Database Syst Rev 2008; 3:CDo01824.

32. Manchikanti L, Singh V, Rivera JJ, Pampati V, Beyer CD, Damron KS, Barnhill RC. Effectiveness of caudal epidural in jections in discogram positive and negative chronic low back pain. Pain Physician 2002; 5:18-29.

33. Manchikanti L, Pampati V, Rivera JJ, Beyer CD, Damron KS, Barnhill RC. Caudal epidural injections with Sarapin steroids in chronic low back pain. Pain Physician 2001; 4:322-335.

34. Butterman GR. The effect of spinal steroid injections for degenerative disc disease. Spine J 2004; 4:495-505.

35. Moher D, Schulz KF, Altman D, for the CONSORT Group. The CONSORT statement: Revised recommendations for improving the quality of reports of parallel-group randomized trials. JAMA 2001; 285:1987-1991.

36. Piaggio G, Elbourne DR, Altman DG, Pocock SJ, Evans SJ. Reporting of noninferiority and equivalence randomized trials: An extension of the CONSORT statement. JAMA 2006; 295:1152-1160.

37. Manchikanti L, Hirsch JA, Smith HS. Evidence-based medicine, systematic reviews, and guidelines in interventional pain management: Part 2. Randomized controlled trials. Pain Physician 2008; 11:717-773.

38. Fairbank JCT, Pynsent PB. The Oswestry disability index. Spine 2000; 25:29402953.

39. Manchikanti L, Singh V, Falco FJ, Cash KA, Pampati V. Lumbar facet joint nerve blocks in managing chronic facet joint pain: One-year follow-up of a randomized, double-blind controlled trial: Clinical Trial NCTo0355914. Pain Physician 2008; 11:121-132.

40. Manchikanti L, Singh V, Falco FJ, Cash KA, Fellows B. Cervical medial branch blocks for chronic cervical facet joint pain: A randomized double-blind, controlled trial with one-year follow-up. Spine 2008; 33:1813-1820.

41. Manchikanti L, Singh V, Falco FJE, Cash KA, Pampati V. Effectiveness of thoracic medial branch blocks in managing chronic pain: A preliminary report of a randomized, double-blind controlled trial; Clinical trial NCT00355706. Pain Physician 2008; 11:491-504.

42. Gammaitoni AR, Fine $P$, Alvarez $N$, McPherson M, Bergmark S. Clinical application of opioid equianalgesic data. Clin J Pain 2003; 19:286-297.

43. Browner WS, Newman TB, Cummings SR, Hulley SB. Estimating sample size and power. In Hulley SB, Cummings SR, Browner WS, Grady D, Hearst N, Newman TB (eds). Designing Clinical Re search: An Epidemiologic Approach, 2nd ed. Lippincott, Williams \& Wilkins, Philadelphia, 2001, pp 65-84.

44. Koes BW, Scholten RJ, Mens JM, Bouter LM. Efficacy of epidural steroid injections for low-back pain and sciatica: A systematic review of randomized clinical trials. Pain 1995; 63:279-288.

45. Manchikanti L, Singh V, Cash KA, Pam pati V, Damron KS, Boswell MV. Preliminary results of randomized, equivalence trial of fluoroscopic caudal epidural injections in managing chronic low back pain: Part 2. Disc herniation and radiculitis. Pain Physician 2008;11:801-815.

46. Manchikanti L, Singh V, Cash KA, Pam pati V, Datta S. Preliminary results of randomized, equivalence trial of fluoroscopic caudal epidural injections in managing chronic low back pain: Part 3. Post surgery syndrome. Pain Physician 2008; 11:817-831.

47. Manchikanti L, Cash KA, McManus CD, Pampati V, Abdi S. Preliminary results of randomized, equivalence trial of fluoroscopic caudal epidural injections in managing chronic low back pain: Part 4. Spinal stenosis. Pain Physician 2008; 11: 833-848.

48. Hotopf M. The pragmatic randomized controlled trial. Adv Psychiatr Treat 2002; 8:326-333.

49. Hotopf M, Lewis G, Normand C. Putting trials on trial: The costs and consequences of small trials in depression: A systematic review of methodology. J Epidemiol Community Health 1997; 51:354-358.

50. Hotopf M, Churchill R, Lewis G. Pragmatic randomized controlled trials in psychiatry. $\mathrm{Br} /$ Psychiatry 1999; 175:217-223.

51. Tunis SR, Stryer DB, Clancy CM. Practical clinical trials. Increasing the value of clinical research for decision making in clinical and health policy. JAMA 2003; 290:1624-1632.

52. Roland M, Torgerson DJ. What are pragmatic trials? BMJ 1998; 316:285.

53. International Conference on Harmonisation of Technical Requirements for Registration of Pharmaceuticals for Human Use. ICH Harmonised Tripartite Guideline. Choice of Control Group and Related Issues in Clinical Trials E10. July 20, 2000.

54. Manchikanti L. Role of neuraxial steroids in interventional pain management. Pain Physician 2002; 5:182-199.

55. Manchikanti L. Pharmacology of neuraxial steroids. In Manchikanti L, Singh $\mathrm{V}$ (eds). Interventional Techniques in Chronic Spinal Pain, ASIPP Publishing, Paducah, KY, 2007; pp 167-184.

56. Byrod G, Otani K, Brisby H, Rydevik B, Olmarker K. Methylprednisolone reduces the early vascular permeability increase in spinal nerve roots induced by epidural nucleus pulposus application. J Orthop Res 2000; 18:983-987.

57. Flower RJ, Blackwell GJ. Anti-inflammatory steroid induced biosynthesis of a phospholipase A2 inhibitor which prevents prostaglandin generation. Nature 1979; 278:456-459.

58. Lundin A, Magnuson A, Axelsson K, Nilsson O, Samuelsson L. Corticoste- 
roids preoperatively diminishes damage to the C-fibers in microscopic lumbar disc surgery. Spine 2005; 30:23622367.

59. Hua SY, Chen YZ. Membrane receptormediated electrophysiological effects of glucocorticoid on mammalian neurons. Endocrinology 1989; 124:687691.

60. Hayashi N, Weinstein JN, Meller ST, Lee HM, Spratt KF, Gebhart GF. The effect of epidural injection of betamethasone or bupivacaine in a rat model of lumbar radiculopathy. Spine 1998; 23:877885 .

61. Lee HM, Weinstein JN, Meller ST, Hayashi N, Spratt KF, Gebhart GF. The role of steroids and their effects on phospholipase A2: An animal model of radiculopathy. Spine 1998; 23:11911196.

62. Minamide A, Tamaki T, Hashizume H, Yoshida M, Kawakami M, Hayashi N. Effects of steroids and lipopolysaccharide on spontaneous resorption of herniated intervertebral discs: An experimental study in the rabbit. Spine 1998 23:870-876.

63. Pasqualucci A, Varrassi G, Braschi A, Peduto VA, Brunelli A, Marinangeli $F$, Gori F, Colò F, Paladín A, Mojoli F. Epidural local anesthetic plus corticosteroid for the treatment of cervical brachial radicular pain: Single injection verus continuous infusion. Clin J Pain 2007; 23:551-557.

64. Katz WA, Rothenberg $R$. The nature of pain: Pathophysiology. I Clin Rheumatol 2005; 11(2 suppl):S11-15.

65. Melzack R, Coderre TJ, Katz J, Vaccarino AL. Central neuroplasticity and pathological pain. Ann N Y Acad Sci 2001; 933:157-174.

66. Kawakami M, Weinstein JN, Chatani K, Spratt KF, Meller ST, Gebhart GF. Experimental lumbar radiculopathy. Behavioral and histologic changes in a model of radicular pain after spinal nerve root irritation with chromic gut ligatures in the rat. Spine 1994; 19:1795-1802.

67. Decosterd I, Woolf CJ. Spared nerve injury: An animal model of persistent peripheral neuropathic pain. Pain 2000; 87:149-158.

68. Pennypacker KR, Hong JS, McMillian MK. Implications of prolonged expression of Fos-related antigens. Trends Pharmacol Sci 1995; 16:317-321.
69. Ji RR, Woolf CJ. Neuronal plasticity and signal transduction in nociceptive neurons: Implications for the initiation and maintenance of pathological pain. $\mathrm{Neu}$ robiol Dis 2001; 8:1-10.

70. Mao J, Chen LL. Systemic lidocaine for neuropathic pain relief. Pain 2000; 87:7-17.

71. Pasqualucci A. Experimental and clinical studies about the preemptive analgesia with local anesthetics. Possible reasons of the failure. Minerva Anestesiol 1998; 64:445-457.

72. Ferrante FM, Paggioli J, Cherukuri S, Arthru GR. The analgesic response to intravenous lidocaine in the treatment of neuropathic pain. Anesth Analg 1996; 82:91-97.

73. Arner S, Lindblom U, Meyerson BA, Mo lander C. Prolonged relief of neuralgia after regional anesthetic block. A call for further experimental and systematic clinical studies. Pain 1990; 43:287297.

74. Lavoie PA, Khazen T, Filion PR. Mechanisms of the inhibition of fast axonal transport by local anesthetics. Neuropharmacology 1989; 28:175-181.

75. Bisby MA. Inhibition of axonal transport in nerves chronically treated with local anesthetics. Exp Neurol 1975; 47:481-489.

76. Cassuto J, Sinclair R, Bonderovic M. Anti-inflammatory properties of local anesthetics and their present and potential clinical implications. Acta An aesthesiol Scand 2006; 50:265-282.

77. Wertheim HM, Rovenstine EA. Suprascapular nerve block. Anesthesiology 1941; 2:541.

78. Riew KD, Park JB, Cho YS, Gilula L, Patel A, Lente LG, Bridwell KH. Nerve root blocks in the treatment of lumbar radicular pain. A minimum five-year follow-up. J Bone Joint Surg Am 2006; 88:1722-1725.

79. Riew KD, Yin Y, Gilula L, Bridwell KH, Lente LG, Lauryssen C, Goette K. The effect of nerve-root injections on the need for operative treatment of lumbar radicular pain. A prospective, randomized, controlled, double-blind study. $J$ Bone Joint Surg Am 2000; 82-A:15891593.

80. Abram SE, Likavec MJ. Pain syndromes and rationale for management. Neurogenic pain. In Raj P (ed). Practical Management of Pain. Year Book Medical
Publishers, Chicago, 1986, pp 182-191.

81. Bonica JJ. Current role of nerve blocks in diagnosis and therapy of pain. In Bonica JJ (ed.) Advances in Neurology, Vol. 4. Raven Press, New York, 1974, pp 445-453.

82. Kibler RF, Nathan PW. Relief of pain and paraesthesiae by nerve block distal to a lesion. J Neurol Neurosurg Psychiat 1960; 23:91-98.

83. Manchikanti L. Interventional pain management: Past, present, and future. The Prithvi Raj lecture: Presented at the 4 th World Congress-World Institute of Pain, Budapest, 2007. Pain Pract 2007; 7:357-371.

84. Sato C, Sakai A, Ikeda Y, Suzuki H, Sakamoto A. The prolonged analgesic effect of epidural ropivacaine in a rat model of neuropathic pain. Anesth Analg 2008; 106:313-320.

85. Tachihara H, Sekiguchi M, Kikuchi S, Konno S. Do corticosteroids produce additional benefit in nerve root infiltration for lumbar disc herniation. Spine 2008; 33:743-747.

86. Aoki Y, Rydevik B, Kikuchi S. Local application of disc-related cytokines on spinal nerve roots. Spine 2002; 27:16141617.

87. Hou SX, Tang JG, Chen HS, Chen J. Chronic inflammation and compression of the dorsal root contribute to sciatica induced by the intervertebral disc herniation in rats. Pain 2003; 105:255264.

88. Igarashi T, Kikuchi S, Myers RR. Exogenous tumor necrosis factor-alpha mimics nucleus pulposus-induced neuropathology. Molecular, histologic, and behavioral comparisons in rats. Spine 2000; 25:2975-2980.

89. McCarron RF, Wimpee MW, Hudkins PG, Laros GS. The inflammatory effect of nucleus pulposus: A possible element in the pathogenesis of low-back pain. Spine 1987; 12:760-764.

90. Olmarker K, Rydevik B, Nordberg C. Autologous nucleus pulposus induces neurophysiologic and histologic changes in porcine cauda equina nerve roots. Spine 1993; 18:1425-1432.

91. Norimoto M, Ohtori S, Yamashita M, Inoue G, Yamauchi K, Koshi T, Suzuki M, Orita S, Eguchi Y, Sugiura A, Ochiai N, Takaso M, Takahashi K. Direct application of the TNF-alpha inhibitor, etanercept, does not affect CGRP expression 
and phenotypic change of DRG neurons following application of nucleus pulposus onto injured sciatic nerves in rats. Spine 2008; 33:2403-2408.

92. Olmarker K, Myers RR. Pathogenesis of sciatic pain: Role of herniated nucleus pulposus and deformation of spinal nerve root and dorsal ganglion. Pain 1998; 78:99-105.

93. Ohtori S, Inoue G, Koshi T, Ito T, Doya H, Saito T, Moriya H, Takahashi K. Upregulation of acid-sensing ion channel 3 in dorsal root ganglion neurons following application of nucleus pulpo sus on nerve root in rats. Spine 2006; 31:2048-2052.

94. Hadjipavlou AG, Tzermiadianos MN, Bogduk N, Zindrick MR. The pathophysiology of disc degeneration: A crit ical review. J Bone Joint Surg Br 2008;
90:1261-1270.

95. Genevay S, Finckh A, Payer M, Mezin F, Tessitore E, Gabay C, Guerne PA. Elevated levels of tumor necrosis factoralpha in periradicular fat tissue in patients with radiculopathy from herniated disc. Spine 2008; 33:2041-2046.

96. Sugiura A, Ohtori S, Yamashita M, Inoue G, Yamauchi K, Koshi T, Suzuki M, Norimoto M, Orita S, Eguchi Y, Takahashi Y, Watanabe TS, Ochiai N, Takaso $M$, Takahashi K. Existence of nerve growth factor receptors, tyrosine $\mathrm{ki}$ nase $a$ and $p 75$ neurotrophin receptors in intervertebral discs and on dorsal root ganglion neurons innervating intervertebral discs in rats. Spine 2008; 33:2047-2051.

97. Yamashita M, Ohtori S, Koshi T, Inoue
G, Yamauchi K, Suzuki M, Takahashi $\mathrm{K}$. Tumor necrosis factor-alpha in the nucleus pulposus mediates radicular pain, but not increase of inflammatory peptide, associated with nerve damage in mice. Spine 2008; 33:1836-1842.

98. Johansson A, Hao J, Sjolund B. Local corticosteroid application blocks transmission in normal nociceptive C-fibres. Acta Anaesthesiol Scand 1990; 34:335338.

99. Mackinnon SE, Hudson AR, Gentili F, Kline DG, Hunter D. Peripheral nerve injection injury with steroid agents. Plast Reconstr Surg 1982; 69:482-489.

100. Shishido H, Kikuchi S, Heckman H, Myers RR. Dexamethasone decreases blood flow in normal nerves and dorsal root ganglia. Spine 2002; 27:581-586. 